\title{
Influence of Consumers' Socio-Economic Characteristics and Attitude on Purchase Intention of Green Products
}

\author{
${ }^{1}$ Dr. N. Mahesh, ${ }^{2}$ Dr. R. Ganapathi \\ ${ }^{I}$ Professor, Dhanraj Baid Jain Institute of Management, IT Corridor, Jyothi Nagar, Thoraipakkam, \\ Chennai- 600097. \\ ${ }^{2}$ Assistant Professor, Directorate of Distance Education, Alagappa University, Karaikudi-630 003.
}

\begin{abstract}
The purpose of this study is to investigate the influence of consumers' socio-economic characteristics and attitude on intention to purchase green products among the consumers in Chennai. The Theory of Planned Behavior is used in this study to investigate the consumers' attitude and intention to purchase green products. This study shows that the intention of consumers to purchase green products is determined by having a positive attitude, subjective norms (green movement) and perceived behaviour control (green foods are concerned about the environment and food safety). Furthermore, the findings of this study indicate that external variables such as educational qualification and monthly income are significant socio-economic determinants of consumers' intention to purchase green products. Consumers who have a higher monthly income and educational qualification are more likely to be concerned about the environment and therefore tend to purchase green products.
\end{abstract}

Key Words: Consumers' Attitude, Consumers' Purchase Intention, Green Products.

\section{Introduction}

Our lifestyle has changed in this fast paced world as compared to few decades ago. During the past 30 years, the society's concern about the environment has increased focusing on ecological awareness, such as warnings of natural resource scarcity, loss of biodiversity and global warming. The subjects have changed from local problems to more global questions, due to an imbalance in the ecological system caused by excessive human consumption and behaviour.

However, current environmental dreadful conditions are ever more menacing consumer health and wellbeing globally. Therefore, consumers are becoming more sensitive in their environmental attitudes, preferences and purchases (Sarigollu, 2009). These days, a large number of consumers all over the world state that they are concerned or very concerned with environmental problems (Diekmann and Franzen, 1999; Dunlap and Mertig, 1995).

In recent times, the environment has emerged as a hot issue for societies, governments, in addition to business organizations. Its significance originates from escalating environmental degradation such as solid wastes, ozone depletion, global warming and air pollution. It is observed that different activities of business organizations like sourcing, manufacturing, logistics, and marketing have a negative impact on the environment and also considered to be the source of most of the environmental problems (Eltayeb, et.al., 2010). Though, environmental destruction has always been part of the human story. All through time, people's health, both on the individual and the community level have been affected through environmental problems (Khwaja, 2008).

The concern for environmental degradation has resulted in a new segment of consumers, i.e. the green consumers. These consumers have been identified as one who avoids products which are possible danger for health, damage the environment during production, use materials derived from threatened species or environment and cause unnecessary waste. Moreover, due to the businesses' decision to respond to these consumers' environmental needs green marketing has' started to become an important branch of learning (Finisterra do Paço, and Raposo, 2008).

Therefore, green marketing is one of the major trends in modern business (Kassaye, 2001). It is used to satisfy the consumers' wants, needs, protect the environment and benefits to the society in a more environmental friendly way (Welford, 2000). However, in reality, the companies which adopted green marketing have encounter a number of challenges which include the variability of demand, majority of the consumers are not aware of the green products and their uses, unfavorable consumer's attitude towards green products, high cost invested in developing green products which require huge investment in research and development and majority of the consumers are not willing to pay a premium for green products. With this background, the present research is attempted to study the influence of consumers' socio-economic characteristics and attitude on intention to purchase green products in Chennai. 


\section{Methodology}

\subsection{Conceptual Framework}

The Theory of Planned Behaviour (TPB) is used to find the factors that affect consumers' attitude towards green products and the consumers' attitude towards environment, health, food safety and animal welfare. TPB assumes the attitude of consumers towards a particular behaviour, subjective norms and perceived behavioural control which are three main conceptual independent determinants of the purchase intention of green products.

The consumers' attitude towards environment, health, food safety and animal welfare are made up of their belief which they accumulate from their lifetime. Subjective norm of this study includes environmentalists and green movement. In other words, subject norm mean how others or people who are important to the consumers can influence their attitude towards green products. Perceived behavioural control is described as people's behaviour or factors which will make the behaviour easy or more difficult to perform (Ajzen, 2002). The Figure-1 shows the conceptual framework of TPB for green products among the consumers in Chennai.

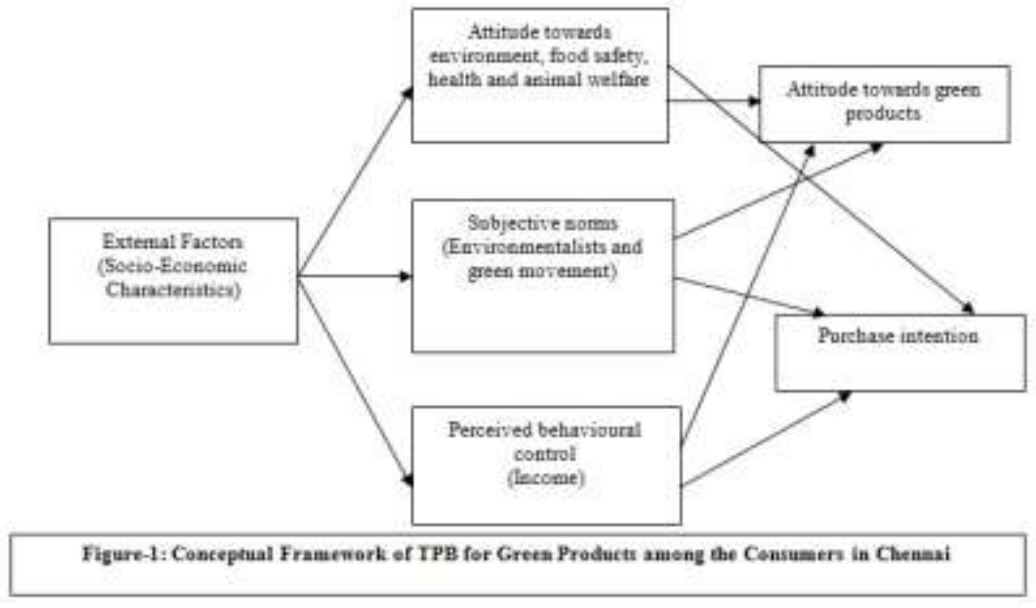

\subsection{Sampling and Method of Analysis}

Among the different cities in Tamil Nadu, the Chennai city has been purposively selected for the present study. The consumers have been selected by adopting random sampling technique through pre-tested and structured questionnaire. The questions are measured by using Likert five point scale (1 represents strongly disagree and 5 represents strongly agree). The data and information have been collected from 300 consumers and pertain to the year 2012-2013. To accomplish the objective of the present study, the descriptive statistics, ANOVA test, Chi-Square analysis and binary logit regression have been applied.

\subsection{Socio-Economic Characteristics of Consumers}

\section{Results And Discussion}

The socio-economic characteristics of consumers were analyzed and the results are presented in Table1. The results indicate that about 54.00 per cent of the consumers are males while the rest of 46.00 per cent of the consumers of are females. The results also show that about 41.33 of the consumers are employed in private sector followed by government ( 36.67 per cent) and business (22.00 per cent). It is clear that about 44.00 per cent of the consumers belong to the age group of 26-40 years followed by 41-60 years (28.00 per cent), below 25 years (19.33 per cent) and above 60 years (8.67 per cent).

The majority of the consumers ( 40.67 per cent) are graduates followed by post graduates ( 22.67 per cent), higher secondary education (15.33 per cent), professionals (12.00 per cent) and secondary education (9.33 per cent). The results also show that about 44.67 per cent of the consumers belong to the monthly income of more than Rs. 20001- 40000 followed by Rs.10001-20000(25.33 per cent), below Rs, 10000(17.33 per cent) and more than Rs. 40000 (12.67 per cent). It is apparent that about 70.67 per cent of the consumers are married while the rest of 29.33 per cent of the consumers are unmarried and about 76.00 per cent of the consumers belong to the nuclear family, while the rest of 24.00 per cent of the consumers belong to the joint family.

\subsection{Consumers' Attitude and Purchase Intention towards Green Products}

The consumers' attitude and purchase intention towards green products was analyzed and the results are presented in Table-2. The results show that consumers are concerned about their food safety, the protection of the environment and animal welfare. Moreover, most of the consumers are strongly agreed that green products are easy to access. The majority of the consumers felt that the green movement makes them aware of the green products. Overall, the analysis indicates that the consumers have a positive attitude and purchase intention towards green products. The F-value of 23.842 is significant at one per cent level of significance 
Influence Of Consumers' Socio-Economic Characteristics And Attitude On Purchase Intention Of indicating that there is a significant difference in attitude and purchase intention towards green products among the consumers.

Table-1. Socio-Economic Characteristics of Consumers

\begin{tabular}{|l|c|c|}
\hline \multicolumn{1}{|c|}{ Particulars } & Frequency & Per cent \\
\hline Gender & & 54.00 \\
\hline Male & 162 & 46.00 \\
\hline Female & 138 & \\
\hline Age( Years) & 58 & 19.33 \\
\hline Below 25 & 132 & 44.00 \\
\hline $26-40$ & 84 & 28.00 \\
\hline $41-60$ & 26 & 8.67 \\
\hline Above 60 & & \\
\hline Educational Qualification & 28 & 9.33 \\
\hline Secondary & 46 & 15.33 \\
\hline Higher Secondary & 122 & 40.67 \\
\hline Graduates & 68 & 22.67 \\
\hline Post Graduates & 36 & 12.00 \\
\hline Professionals & & 22.00 \\
\hline Occupation & 66 & 36.67 \\
\hline Business & 110 & 41.33 \\
\hline Government & 124 & 17.33 \\
\hline Private & & 25.33 \\
\hline Monthly Income(Rs.) & 52 & 44.67 \\
\hline Below 10000 & 76 & 12.67 \\
\hline 10001-20000 & 134 & 70.67 \\
\hline 20001-40000 & 38 & 29.33 \\
\hline$>40000$ & & 76.00 \\
\hline Marital Status & 212 & 24.00 \\
\hline Married & 88 & \\
\hline Unmarried & & \\
\hline Family Type & 228 & \\
\hline Nuclear & 72 & \\
\hline Joint & & \\
\hline & & \\
\hline & & \\
\hline
\end{tabular}

Table-2. Consumers' Attitude and Purchase Intention towards Green Products

\begin{tabular}{|c|c|c|c|c|c|c|c|c|}
\hline \multirow[t]{2}{*}{ Statements } & \multicolumn{5}{|c|}{ Level of Agreement (\%) } & \multirow{2}{*}{$\begin{array}{l}\text { Mean } \\
\text { Score }\end{array}$} & \multirow{2}{*}{$\begin{array}{c}\text { F- } \\
\text { Value }\end{array}$} & \multirow[t]{2}{*}{ Sig } \\
\hline & SA & $\mathbf{A}$ & $\mathbf{N}$ & DA & SDA & & & \\
\hline $\begin{array}{l}\text { I intend to purchase green foods } \\
\text { because they are more concerned } \\
\text { about food safety. }\end{array}$ & 45.20 & 26.80 & 14.75 & 7.50 & 5.75 & 4.88 & & \\
\hline $\begin{array}{l}\text { I want to purchase green foods } \\
\text { because they are more } \\
\text { environmentally friendly. }\end{array}$ & 42.75 & 37.50 & 11.50 & 4.25 & 4.00 & 4.76 & & \\
\hline $\begin{array}{l}\text { I plan to purchase green foods } \\
\text { because I am concerned about } \\
\text { animal welfare. }\end{array}$ & 32.25 & 34.75 & 9.50 & 11.50 & 12.00 & 4.72 & 23.842 & 0.01 \\
\hline $\begin{array}{l}\text { I believe green food is available } \\
\text { and easy to access. }\end{array}$ & 33.50 & 37.50 & 12.75 & 11.50 & 4.75 & 4.58 & & \\
\hline $\begin{array}{l}\text { The green movement makes me } \\
\text { aware of the green products }\end{array}$ & 42.75 & 37.50 & 12.50 & 3.50 & 3.75 & 4.62 & & \\
\hline
\end{tabular}

\subsection{Relationship between Socio-Economic Characteristics and Consumers' Attitude towards Green Products}

The relationship between socio-economic characteristics and consumers' attitude towards green products was analyzed by adopting Chi-Square test and the results are presented in Table-3. 
Influence Of Consumers' Socio-Economic Characteristics And Attitude On Purchase Intention Of

Table-3. Socio-Economic Characteristics and Consumers' Attitude towards Green Products

\begin{tabular}{|l|c|}
\hline \multicolumn{1}{|c|}{ Socio-Economic Characteristics } & Chi-Square Value \\
\hline Gender & 0.846 \\
\hline Occupation & $2.642^{* * *}$ \\
\hline Age & $3.148^{* *}$ \\
\hline Educational Qualification & $2.426^{* *}$ \\
\hline Monthly Income & $3.595^{* *}$ \\
\hline Marital Status & 0.645 \\
\hline Family Type & 0.492 \\
\hline
\end{tabular}

Note: ${ }^{* *}$ indicates significant at one per cent level.

The results show that consumers who have a higher education level are more likely to purchase green products than the consumers who have a low education level. In addition, the consumers who have a higher income were more intent on purchasing green products than middle and low income levels. Besides the middle age consumers and employees of private sector have more intention in purchasing of green products.

\subsection{Influence of Consumers' Socio-Economic Characteristics and Attitude on Intention to Purchase Green Products}

The influence of consumers' socio-economic characteristics and attitude on intention to purchase green products was analyzed by employing binary logit regression and the results are presented in Table-4. It is attempted to determine the extent to which selected socio-economic characteristics and attitudes influence the consumers' intention to purchase green products. The dependent variable; "intent to purchase green products" had two categories which are "consumers' intent to purchase green products" coded as one and otherwise was coded as zero. The result of this study found that out of the eight variables, four variables were positive and statistically significant. Thus, the socio-economic characteristics and consumers' perceived behavioural control are relevant in explaining the consumers' intention to purchase green products.

Table-4. Influence of Consumers' Socio-Economic Characteristics and Attitude on Intention to Purchase Green Products

\begin{tabular}{|l|c|c|c|}
\hline \multicolumn{1}{|c|}{ Variables } & $\begin{array}{c}\text { Estimated } \\
\text { Coefficient }\end{array}$ & $\begin{array}{c}\text { Significant } \\
\text { Level }\end{array}$ & Exp(B) \\
\hline Gender & -0.032 & 0.582 & 0.862 \\
\hline Age & -0.014 & 0.746 & 0.972 \\
\hline Educational Qualification & 0.546 & $0.000^{* *}$ & 1.764 \\
\hline Monthly Income & 0.892 & $0.000^{* *}$ & 2.756 \\
\hline Marital Status & 0.069 & 0.642 & 1.126 \\
\hline Environmental Friendliness & 0.566 & $0.012^{*}$ & 1.714 \\
\hline Food Safety & 0.464 & $0.034^{*}$ & 1.418 \\
\hline Animal Welfare & 0.356 & 0.146 & 1.216 \\
\hline Constant & -1.524 & $0.001^{* *}$ & 0.052 \\
\hline -2 Log Likelihood & \multicolumn{3}{|c|}{148.462} \\
\hline Nagelkerke R Square & \multicolumn{3}{|c|}{0.182} \\
\hline Cox and Snell R Square & \multicolumn{3}{|c|}{0.124} \\
\hline Hosmer and Lemeshow Test & \multicolumn{3}{|l}{} \\
\hline
\end{tabular}

Note: ** indicates one per cent level and * indicates five per cent level of significance

Based on the statistically significant coefficients, the level of environmental friendliness is an important determinant for consumer intention to purchase green products and the effect is positive .This finding indicates that consumers who have high environmental concerns were 1.714 times more intent to purchase green products than consumers' who do not think that green product is concerned with the environment. The coefficient for food safety is positive and significant at the five per cent level of significance.

This shows that when the consumers are concerned more about food safety, the likelihood of level of intention increases 1.418 times compared to consumers who are less concerned about food safety. The educational qualification and income are the only socio-economic characteristics which had a positive sign and are significant at one per cent level of significance. The results show that consumers who have a higher education level have 1.764 times more intention to purchase green products than that of consumers who have lower educational qualifications.

Similarly, for the consumers who have a higher monthly income, the likelihood of their level of intention to purchase green products increases 2.756 times that of consumers with a low monthly income level. The logit model has three important determinants which are intention, subjective norms and perceived 
behavioural control. Attitude towards green foods, subjective norms and perceived behavioural control (environmentally friendly and food safety) are the significant predictors of the consumers' intention to purchase green products.

\section{Conclusion}

The purpose of this study is to investigate the influence of consumers' socio-economic characteristics and attitude on intention to purchase green products among the consumers in Chennai. The Theory of Planned Behavior is used in this study to investigate the consumers' attitude and intention to purchase green products. This study shows that the intention of consumers to purchase green products is determined by having a positive attitude, subjective norms (green movement) and perceived behaviour control (green foods are concerned about the environment and food safety).

Furthermore, the findings of this study indicate that external variables such as educational qualification and monthly income are significant socio-economic determinants of consumers' intention to purchase green products. Consumers who have a higher monthly income and educational qualification are more likely to be concerned about the environment and therefore tend to purchase green products.

In addition, green products are still an emerging concept in Chennai, but it can become more popular among consumers of Chennai, if the society is made to be more aware of the issues concerning the environment, food safety and animal welfare. Therefore, improving public awareness and positive attitudes towards the green consumerism and green products will increase consumers' intentions to purchase green products. It is important for the producers, processors, manufacturers or marketers to understand consumers' behaviour and intention towards purchasing green products so that they can increase their awareness and knowledge on green products in order to improve the consumers' purchasing behaviour of green products.

\section{References}

[1] Sarigollu, E. (2009). A Cross-Country Exploration of Environmental Attitudes. Environment and Behavior, 41(3): $365-386$.

[2] Diekmann, A. and Franzen, A.(1999). The Wealth of Nations and Environmental Concern. Environment and Behavior, 31: 540549 .

[3] Dunlap, R.E. and Mertig, A.G.(1995). Global Concern for the Environment: Is Affluence a Prerequisite?. Journal of Social Issues, 51: $121-137$

[4] Eltayeb, T.K. Zailani, S. and Jayaraman,K.(2010). The Examination on the Drivers for Green Purchasing Adoption among EMS 14001 Certified Companies in Malaysia. Journal of Manufacturing Technology Management, 21(2): 206-225.

[5] Khwaja,Z.R.(2008).Consumer Voice, Consumer Rights Council, SINDH.06, from www.crc.org.pk.

[6] Finisterra do Paço, A.M. and Raposo, M.L.B.(2008). Determining the Characteristics to Profile the "Green" Consumer: An Exploratory Approach. Int Rev Public Nonprofit Mark, 52: 129-140.

[7] Kassaye,W.W.(2001). Green Dilemma,,Marketing. Intelligence and Planning, 19(6): 444-455.

[8] Welford,R.(2000). Ilijacking Environmentalism, Earthscan, London,

[9] Ajzen, I.(2002). Perceived Behavioural Control, Self-Efficacy, Locus of Control and the Theory of Planned Behaviour. Journal of Applied Social Psychology, 32(4):665-683. 